\title{
The mxaAKL genes of Methylobacter albus BG8
}

\author{
Peggy J. Arps, $\uparrow$ Brenda S. Speer,$\ddagger$ Young M. Kim $§$ and Mary E. Lidstrom
}

Author for correspondence: Mary E. Lidstrom. Tel: +1 818395 2132. Fax: +18183952940.

e-mail: lidstrom@cco.caltech.edu

Keck Laboratories, 138-78, California Institute of Technology, Pasadena, CA 91125, USA

\begin{abstract}
The facultative methanol utilizer Methylobacterium extorquens AM1 contains at least three genes ( $m \times a A, K$ and $L$ ) that encode functions involved in providing calcium to the holoenzyme of methanol dehydrogenase, the enzyme that oxidizes methanol to formaldehyde in this strain. Methane-utilizing bacteria (methanotrophs) also contain methanol dehydrogenase, and evidence suggests that similar methanol oxidation (Mox) functions may be present in some of these strains. DNA fragments from Methylobacterium extorquens AM1 specific to $m \times a A, m x a K$ and $m x a L$ were isolated for use as hybridization probes against genomic digests of a variety of methanotrophic bacteria. Only the mxal probe showed substantial hybridization, and it was used to identify and isolate an $8.5 \mathrm{~kb}$ HindIII fragment from Methylobacter albus BG8 (a Type I methanotroph). Hybridization of restriction digests of this fragment to individual probes for Methylobacterium extorquens AM1 mxaA, $K$ and $L$ indicated that the relative mxa gene order in Methylobacter albus BG8 is A-K-L. A T7 dual promoter/polymerase protein expression system indicated that five polypeptides are expressed from a $4.5 \mathrm{~kb}$ region of Methylobacter albus BG8 DNA in Escherichia coli, all transcribed in the same direction, and they apparently correspond to mxaACKDL. The functions of mxaC and mxaD are currently not known, but the order of $m \times a D L$ is reversed in Methylobacter albus BG8 compared to Methylobacterium extorquens AM1. When subclones of the Methylobacter albus BG8 fragment containing these genes were used as hybridization probes to genomic digests of methanotrophic bacteria, specific bands were detected that suggested a similar gene order in most cases. These data indicate that the mxaAKL region is relatively highly conserved in methanotrophs, and that in most cases the mxaAKL genes are grouped together in the same order as in the facultative methanol utilizer Methylobacterium extorquens AM1.
\end{abstract}

Keywords : methanotroph, mox genes, calcium insertion, methanol oxidation, Metbylobacter albus

\section{INTRODUCTION}

In Gram-negative methylotrophic bacteria, methanol is oxidized to formaldehyde by the periplasmic quinoprotein

†Present address: Applied Microbiology and Biotechnology Inc Glenwood Springs, CO 81602, USA.

$\ddagger$ Present address: Dept of Biochemistry, Microbiology and Molecular Biology, University of Maine, Orono, ME 04469, USA.

\Present address: Dept of Biology, Yonsei University, Seoul 120-749, Korea.

Abbreviations: $M D H$, methanol dehydrogenase; PQQ, pyrroloquinoline quinone.

The GenBank accession number for the Methylobacterium extorquens AM1 $m \times a A C K L D$ sequence is $L 41608$. methanol dehydrogenase (Anthony, 1986). Methanol dehydrogenase (MDH) consists of two large and two small subunits and two molecules of the cofactor pyrroloquinoline quinone (PQQ), which are noncovalently attached to each of the large subunits. In addition, each PQQ site contains a calcium ion, which is apparently involved in maintaining PQQ in the correct configuration (Richardson \& Anthony, 1992; Anthony et al., 1994; White et al., 1993). This enzyme has been shown to be conserved biochemically and antigenically in a variety of methylotrophic bacteria (Anthony, 1986) and at the nucleotide sequence level in three different methanol utilizers (Anderson et al., 1990; Harms et al., 1987; Machlin \& Hanson, 1988). Recent evidence shows that at least 24 complementation groups are involved in the 
oxidation of methanol to formaldehyde (Mox functions) in the facultative methanol utilizer Metbylobacterium extorquens AM1 (Anderson \& Lidstrom, 1988; Lidstrom, 1988; Nunn \& Lidstrom, 1986a, b; Lidstrom et al., 1994) and at least 13 in Metbylobacterium organophilum XX (Bastien et al., 1989; Machlin et al., 1988).

Three of the known Mox complementation groups define $m \times a A, K$ and $L$, which are located immediately $3^{\prime}$ to a cluster of $m \times a$ genes ( $m \times a F J G I R S)$ in Metbylobacterium extorquens AM1 (Nunn \& Lidstrom, 1986a; Lidstrom et al., 1994; Morris et al., 1995). The $m \times a A, K$ and $L$ genes are adjacent on the chromosome and their gene products are involved in the acquisition of calcium ions by the holoenzyme (Richardson \& Anthony, 1992). MDH from mutants of all three classes is inactive, no longer contains calcium, and has an altered absorption spectrum. When the inactive MDH from these mutants was incubated in calcium salts, the full enzyme activity returned over time and the absorption spectrum corresponding to that of fully reduced wild-type $\mathrm{MDH}$ was concomitantly restored (Richardson \& Anthony, 1992). Therefore, the mxaA, $K$ and $L$ gene products may be calcium-binding proteins, may be involved in maintaining a high calcium concentration in the periplasm, or may stabilize a configuration of $\mathrm{MDH}$ that permits incorporation of low calcium concentrations into the protein. Two other genes ( $m \times a C$ and $m \times a D)$ are known to be present in this region, but their function is not yet known (Morris et al., 1995). At this time, it appears that $m \times a A K L$ in Methylobacterium extorquens AM1 are part of a large gene cluster that includes (in order) $m \times a F J G I R S A C K L D$.

The Mox system is clearly complex in facultative methanol utilizers and it is important to determine whether a similar complexity exists in other methylotrophs at both functional and genetic levels. We are particularly interested in the obligate methane-utilizing bacteria (methanotrophs) due to their pivotal role in both commercial (Hou, 1984) and environmental (Thompson \& Cicerone, 1986) processes. Data exist suggesting that the Mox system in methanotrophs shows functional similarity to the Mox system in facultative methanol utilizers, since Mox genes from methanotrophs can complement Mox mutations in Metbylobacterium strains (Stephens et al., 1988; Bastien et al., 1989).

The purpose of the present study was to isolate and characterize $m \times a A, K$ and $L$ genes from a Type I methanotroph. A gene probe derived from cloned Metbylobacterium extorquens AM1 DNA containing mxaL was used to identify specific hybridizing fragments in genomic digests of DNA from a variety of obligate methanotrophs, and to clone $m x a A, K$ and $L$ from Metbylobacter albus BG8. Expression studies suggested that in Metbylobacter albus BG8 this hybridizing region contains at least five genes, equivalent to mxaACKLD of Metbylobacterium extorquens AM1. Functional complementation of Metbylobacterium extorquens AM1 MxaA, $\mathrm{K}$ and $\mathrm{L}$ mutants was not achieved with any of the Metbylobacter albus BG8 fragments tested.

\section{METHODS}

Bacterial strains, plasmids and phage. The bacterial strains, plasmids and bacteriophage used in this study are listed in Table 1.

Media and growth conditions. Metbylobacterium extorquens AM1 was grown at $30^{\circ} \mathrm{C}$ in the ammonium/mineral salts medium described by Harder et al. (1973) supplemented with a vitamin mixture (Staley, 1981) or in nutrient broth (Difco). Escherichia coli strains were grown at $37^{\circ} \mathrm{C}$ in Luria broth (Maniatis et al., 1982). Filter-sterilized supplements were added to media as follows : $0.2 \%(\mathrm{w} / \mathrm{v})$ succinate; $0.5 \%(\mathrm{v} / \mathrm{v})$ methanol; $12.5 \mu \mathrm{g}$ tetracycline $\mathrm{ml}^{-1} ; 10 \mu \mathrm{g}$ rifamycin $\mathrm{ml}^{-1} ; 50 \mu \mathrm{g}$ kanamycin $\mathrm{ml}^{-1}$; and $50 \mu \mathrm{g}$ ampicillin $\mathrm{ml}^{-1}$. Methanotrophs were grown at $30^{\circ} \mathrm{C}$, except Metbylobacter sp. strains A1, A45 and MN, which were grown at $37^{\circ} \mathrm{C}$ and Methylococcus capsulatus strain Bath, which was grown at $42^{\circ} \mathrm{C}$. All methanotrophs were grown in the nitrate mineral salts medium described by Whittenbury \& Dalton (1981) supplemented with a vitamin mixture (Staley, 1981). Methanotrophs were maintained on plates containing medium plus $1.5 \%(\mathrm{w} / \mathrm{v}$ ) Bacto-Agar (Difco) in gas canisters under a methane: air atmosphere $(1: 1)$ and were grown in liquid culture with shaking under an atmosphere of the same composition.

Matings for complementation. Plasmids (pRK310 containing appropriate Metbylobacter albus BG8 DNA inserts or Metbylobacterium extorquens DNA inserts as controls) were mobilized into Metbylobacterium extorquens AM1 in three-way matings as described previously (Stephens et al., 1988), except that Metbylobacterium extorquens strains were taken from fresh agar plates. Additionally, the admixture of strains was spotted directly onto nutrient agar plates instead of filters for overnight incubation.

DNA manipulations. Plasmid DNA was isolated from E. coli either by the rapid screening method of Holmes \& Quigley (1981) or the large-scale method of Ish-Horowicz \& Burke (1981). Plasmid DNA from large-scale preparations was further purified by two rounds of banding in $\mathrm{CsCl} /$ ethidium bromide density gradients.

Chromosomal DNA was prepared by the method of Marmur (1961), scaled down to a $1.5 \mathrm{ml}$ volume.

Restriction enzymes were obtained from BRL or New England Biolabs and were used according to the manufacturers' specifications. Most analytical restriction digests were performed overnight in the presence of RNaseA to ensure complete digestion of the DNA. Chromosomal DNA digests were typically carried out for $4 \mathrm{~h}$ prior to separation and hybridization.

Agarose gel electrophoresis purification of DNA fragments and DNA ligations and transformations of $E$. coli strains were performed as described by Maniatis et al. (1982).

Radiolabelling of DNA was performed by the nick-translation procedure of Rigby et al. (1977) or by a random-priming procedure using the specifications of the supplier (Boehringer Mannheim).

DNA-DNA hybridization. Hybridizations were performed using dried agarose gels as described by Meinkoth \& Wahl (1984). Hybridization incubations for blots containing genomic DNA were carried out at $53^{\circ} \mathrm{C}$ in $6 \times \mathrm{SSC}(1 \times \mathrm{SSC}=0.15 \mathrm{M}$ $\mathrm{NaCl}$ plus $0.015 \mathrm{M}$ sodium citrate), $0.5 \%$ (w/v) SDS, $0.5 \%$ $(\mathrm{w} / \mathrm{v}$ ) non-fat dried milk and 0.01 M EDTA (pH 8.0) followed by four $15 \mathrm{~min}$ washes in $2 \times$ SSC and $0.1 \%$ SDS, two at room temperature and two at $53{ }^{\circ} \mathrm{C}$. For probing of cloned fragments, each lane on the agarose gel was loaded with approximately $1.0 \mu \mathrm{g}$ Metbylobacter albus BG8 DNA $(5.9 \mathrm{~kb}$ EcoRI fragment or $8.5 \mathrm{~kb}$ HindIII fragment) digested with the designated re- 
Table 1. Bacterial strains and plasmids used in this study

\begin{tabular}{|c|c|c|}
\hline Strains & Relevant traits & Source/reference \\
\hline \multicolumn{3}{|l|}{ E. coli } \\
\hline $\mathrm{DH} 5 \alpha$ & $\begin{array}{l}\mathrm{r}^{-} \mathrm{m}^{+} \text {rec } A 1 \phi 80 \mathrm{~d} l a c Z \Delta \mathrm{M} 15(\operatorname{lac} Z Y A-a r g F) \mathrm{U} 169 \text { bsdR } \\
\text { thi-1 gyr } A \text { supE end } A 1 \text { relA1 }\end{array}$ & BRL \\
\hline HB101 & $\begin{array}{l}\mathrm{r}^{-} \mathrm{m}^{-} \text {bsdS rec } A 13 \text { ara-14 sup E lac Y merB galK pro } A \text { xyl-5 mtl-1 } \\
\text { leu-1 rpsL }\end{array}$ & $\begin{array}{l}\text { Boyer \& Roulland-Dussoix } \\
(1969)\end{array}$ \\
\hline \multicolumn{3}{|l|}{ Methanol utilizers } \\
\hline \multicolumn{3}{|l|}{ Methylobacterium extorquens AM1 } \\
\hline AM1 rif & Rifr-derivative & Nunn \& Lidstrom (1986a) \\
\hline AM1 PG1 & MxaA mutant of AM1, rif ${ }^{r}$ & Nunn \& Lidstrom (1986a) \\
\hline AM1 UV4 & MxaK mutant of AM1, rif ${ }^{r}$ & Nunn \& Lidstrom (1986a) \\
\hline AM1 M15a & MxaL mutant of AM1, rifr & Nunn \& Lidstrom (1986a) \\
\hline \multicolumn{3}{|l|}{ Methane utilizers } \\
\hline \multicolumn{3}{|l|}{ Type I } \\
\hline Methylobacter albus BG8 & & $\begin{array}{l}\text { Whittenbury et al. (1970); } \\
\text { Bowman et al. (1993) }\end{array}$ \\
\hline Metbylobacter sp. strain A1 & & Lidstrom (1988) \\
\hline Metbylobacter marinus strain A4 & & $\begin{array}{l}\text { Lidstrom (1988); } \\
\text { Bowman et al. (1993) }\end{array}$ \\
\hline Metbylomonas sp. strain MN & & This laboratory \\
\hline Metbylobacter capsulatus Y & & Whittenbury et al. (1970) \\
\hline \multicolumn{3}{|l|}{ Type II } \\
\hline Metbylosinus trichosporium $\mathrm{OB} 3 \mathrm{~b}$ & & Whittenbury et al. (1970) \\
\hline Metbylosinus sporium 5 & & Whittenbury et al. (1970) \\
\hline Metbylocystis parvus OBBP & & Whittenbury et al. (1970) \\
\hline Metbylocystis sp. strain LWY & & This laboratory \\
\hline \multicolumn{3}{|l|}{ Type X } \\
\hline Metbylococcus capsulatus Bath & & Whittenbury et al. (1970) \\
\hline \multicolumn{3}{|l|}{ Plasmids } \\
\hline pVK100 & $\mathrm{Tc}^{\mathrm{r}} \mathrm{Km}^{\mathrm{r}}$ IncPI cosmid & Knauf \& Nester (1982) \\
\hline pRK310 & $\mathrm{Tc}^{\mathrm{r}}$ lac $P O Z^{\prime}$ IncPI & Ditta et al. (1985) \\
\hline pRK2013 & $\mathrm{Km}^{\mathrm{r}}$-mobilizing plasmid & Figurski \& Helinski (1979) \\
\hline \multicolumn{3}{|c|}{ Plasmids containing inserts of Methylobacterium extorquens AM1 DNA } \\
\hline pDN9 & pVK100 (4.4 kb HindIII-XhoI $) ; m \times a A, K, L$ & Nunn \& Lidstrom (1986a) \\
\hline pYK310 & pRK310 $(0.9 \mathrm{~kb}$ PstI-BamHI);mxaA & \\
\hline pCT2 & pRK310 (0.9 kb SacII-EcoRI); $m \times a K$ & \\
\hline pCT3 & pRK310 $(1 \cdot 8 \mathrm{~kb} S a / \mathrm{I}) ; m \times a L$ & \\
\hline \multicolumn{3}{|c|}{ Plasmids containing inserts of Methylobacter albus BG8 DNA } \\
\hline pYK-B25 & pVK100 (25 kb HindIII) & \\
\hline pYK-BH1 & pRK310 (8.5 kb HindIII) & \\
\hline pYK-BE2 & pRK310 (5.9 kb EcoRI) & \\
\hline pBMX834 & pT76 $(1.4 \mathrm{~kb}$ BamHI-NruI $)$ & \\
\hline pBMX854 & pT76 (3.2 kb BamHI-PstI) & \\
\hline pBMX856 & pT76 (3.5 kb BamHI-EcoRI) & \\
\hline pBMX860 & pT76 (4.0 kb BamHI-BamHI) & This study \\
\hline $\mathrm{pBMX} 854 \Delta \mathrm{BN}$ & pBMX854 with deletion of $1.4 \mathrm{~kb}$ BamHI-NruI & \\
\hline $\mathrm{pBMX} 860 \Delta \mathrm{BN}$ & pBMX860 with deletion of $1.4 \mathrm{~kb}$ Bam HI-NruI & \\
\hline pYK-HH1 & pRK310 (8.5 kb HindIII), orientation right to left (plac) & \\
\hline pYK-HH4 & pRK310 (8.5 kb HindIII), orientation left to right (plac) & \\
\hline pYK-EE1 & pRK310 (5.9 kb EcoRI), orientation right to left (plac) & \\
\hline pYK-EE5 & pRK310 (5.9 kb EcoRI), orientation left to right (plac) & \\
\hline pCT155 & pRK310 (4.0 kb BamHI), orientation right to left (plac) & \\
\hline pCT153 & pRK310 (4.0 kb BamHI), orientation left to right (plac) & \\
\hline pCT158 & pRK310 ( $3.5 \mathrm{~kb}$ PstI-HindIII), orientation right to left (plac) & \\
\hline pCT157 & pRK310 (0.3 kb PstI-EcoRI), orientation left to right (plac) & \\
\hline
\end{tabular}

striction enzyme. Control lanes (either Metbylobacterium extorquens probe DNA alone or pUC19 plasmid DNA containing probe DNA, digested to yield the probe insert) were loaded to give approximately $10 \mathrm{ng}$ probe DNA. Hybridization incubations in these cases were as described above except they were carried out at $42^{\circ} \mathrm{C}$. Washes were performed as follows: once at room temperature followed by once at $53{ }^{\circ} \mathrm{C}$ or at $59^{\circ} \mathrm{C}$.

Colony hybridizations were carried out by the procedure described by Maniatis et al. (1982) using 1-5 $10^{6}$ c.p.m. of ${ }^{32}$ P-labelled probe DNA. 
Protein expression. Protein expression from cloned genes was accomplished using the T7 promoter vectors p T7-5 and pT7-6 and plasmid pGP1-2 containing the $\mathrm{T} 7$ polymerase gene, as described by Tabor (1987). Promoter vectors pT7-5 and pT7-6 each contain a polylinker cloning region downstream of the T7 promoter followed by the ampicillin-resistance gene, which is transcribed in the opposite orientation to the T7 promoter. Each Metbylobacter albus BG8 DNA insert was cloned and tested in both orientations with respect to the $\mathrm{T} 7$ promoter.

\section{RESULTS}

\section{Genomic probing with the $m \times a A, K$ and $L$ genes}

In order to determine whether similarity exists among the $m x a A, K$ and $L$ genes of Metbylobacterium extorquens AM1 and chromosomal DNA obtained from obligate methanotrophs, DNA fragments containing each of these genes were isolated from Metbylobacterium extorquens AM1 to use as hybridization probes. The fragments selected were a $0.9 \mathrm{~kb}$ Pst-BamHI fragment containing $m \times a A$, a $0.9 \mathrm{~kb}$ SacII-EcoRI fragment containing $m \times a K$, and a $1.8 \mathrm{~kb}$ Sall-SalI fragment containing $m \times a L$ (Fig. 1a; Nunn \& Lidstrom, 1986a). The latter fragment is now known to contain $m \times a D$ also (Morris et al., 1995).

Each of these isolated fragments was used to probe EcoRI digests of genomic DNA from several different methanotrophs representing all three major groups (Type I, Type II and Type X). In each case, a variety of stringency

(a) Methylobacterium extorquens AM1

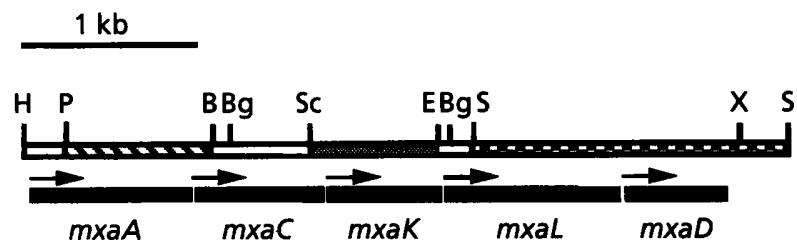

(b) Methylobacter albus B̈G8

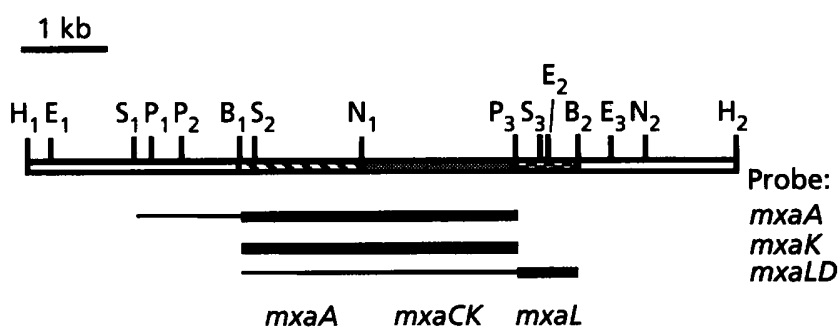

Fig. 1. mxaAKL regions of two methylotrophs. The patterned boxes denote the restriction fragments used for hybridization probes. (a) Methylobacterium extorquens AM1 region showing the location of $m x a A, C, K, L$ and $D$. The arrow above each gene shows the direction of transcription. (b) The Methylobacter albus BG8 insert in PYK-BH1. The lines underneath show the minimum regions that hybridized to the corresponding probes in (a), with the thin lines representing light hybridization. B, BamHI; Bg, BgllI; E, EcoRI; H, Hindlll; N, Nrul; P, Pstl; S, Sall; Sc, Sacll; X, Xhol.

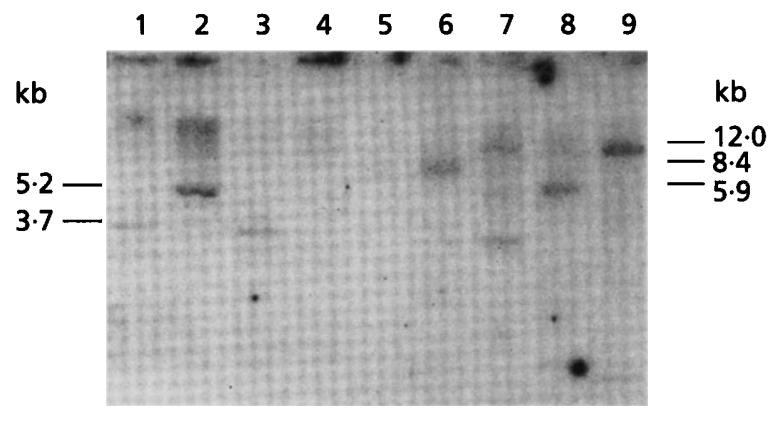

Fig. 2. Hybridization of the isolated Methylobacterium extorquens AM1 mxaLD gene probe to DNA from methanotrophs. Total genomic DNA was digested with EcoRI, separated on agarose gels and dried. Each lane contained approximately $1.5 \mu \mathrm{g}$ total DNA. The dried gels were hybridized to ${ }^{32}$ p-labelled probe DNA (isolated fragment) and exposed to $X$-ray film. Conditions of hybridization allowed approximately $35 \%$ base pair mismatch. Lanes: 1, Methylocystis sp. strain; LWY; 2, Methylosinus trichosporium OB3b; 3, Methylocystis parvus OBBP; 4, Methylomonas sp. strain MN; 5, Methylobacter capsulatus Y; 6, Methylobacter marinus A45; 7, Methylococcus capsulatus Bath; 8, Methylobacter albus BG8; 9, Methylosinus sporium 5 . Sizes of the major hybridizing bands are indicated.

conditions were tested, but conditions allowing 30-37\% base pair mismatch (see Methods) produced the clearest results. With the $m \times a A$ and $m \times a K$ probes, only weak hybridization to specific bands was detected under all conditions tested (data not shown). However, much stronger hybridization was observed in most cases using the $m \times a L D$ probe (Fig. 2). The approximate sizes of the major hybridizing bands are indicated in Fig. 2. Hybridization was detected for two Type I strains, all of the Type II strains and the Type $\mathrm{X}$ strain, but no significant hybridization was detected for two of the Type I strains (Metbylomonas sp. MN and Metbylobacter capsulatus Y) (see Fig. 2). Positive controls containing Metbylobacterium extorquens AM1 genomic DNA identified the predicted $E c o R I$ fragments for each probe and negative controls $(E$. coli and bacteriophage lambda) showed no hybridization (data not shown).

\section{Cloning of the $m x a$ genes from Methylobacter albus BG8}

The data presented above suggest that significant similarity of the mxaLD genes occurs in diverse methylotrophs and some conservation of sequences may also be present in $m \times a A$ and $K$ genes. In order to determine whether the hybridization observed was due to the presence of true $m \times a A, K$ and $L$ homologues, we cloned the corresponding DNA fragments from one of the methanotrophs. Metbylobacter albus BG8 was chosen, since the $m \times a L D$ probe showed good hybridization to Metbylobacter albus BG8 genomic DNA (Fig. 2), and a genomic clone bank (a HindIII partial digest of Metbylobacter albus BG8 DNA ligated to the broad-host-range cosmid vector pVK100) is available for this strain (Stephens et al., 1988). Colony blots of this bank were screened for hybridization to the $m \times a L D$ probe, and positive clones were identified. 


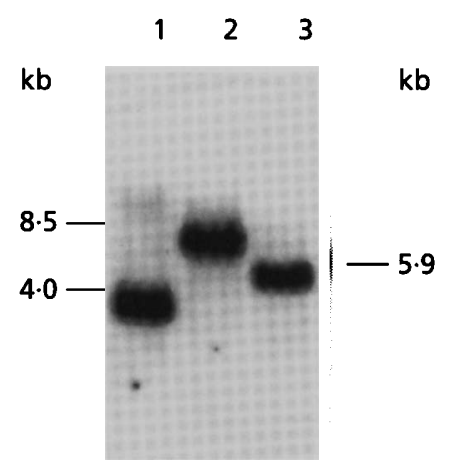

Fig. 3. Hybridization of the cloned Methylobacter albus BG8 $4.0 \mathrm{~kb} B a m \mathrm{HI}$ fragment containing the mxaAKL region to Methylobacter albus BG8 chromosomal DNA digested with different enzymes. Lanes: 1, BamHI; 2, HindIII; 3, EcoRI. Sizes of the hybridizing bands are indicated.

Each of these clones contained an identical set of HindIII fragments of approximately $8.5,7 \cdot 0,3 \cdot 4,3.2,1.4$ and $1.3 \mathrm{~kb}$ in size. The $m \times a L D$ probe hybridized specifically to the $8.5 \mathrm{~kb}$ fragment. This fragment was subcloned into the broad-host-range vector $\mathrm{pRK} 310$ and the insert was mapped using a variety of restriction enzymes (Fig. 1b). This $8.5 \mathrm{~kb}$ region included a $5.9 \mathrm{~kb}$ EcoRI $\left(\mathrm{E}_{1}-\mathrm{E}_{2}\right)$ fragment as identified in the initial genomic blots (Fig. 2). When blots of genomic EcoRI, HindIII and BamHI digests were tested with the $4 \mathrm{~kb}$ Bam HI Metbylobacter albus BG8 fragment $\left(B_{1}-B_{2}\right.$ in Fig. $\left.1 b\right)$ as a probe, restriction fragments of approximately $5.9,8.5$ and $4.0 \mathrm{~kb}$ were detected, respectively (Fig. 3), confirming that the cloned fragment was present in the chromosome of Methylobacter albus BG8.

\section{Identification of the mxaAKL regions}

Each of the Metbylobacterium extorquens AM1 $m \times a$ probes was used for hybridization to restriction digests of the $8.5 \mathrm{~kb}$ HindIII fragment or an appropriate subclone in order to delineate the position of each of the $m \times a$ genes in Metbylobacter albus BG8. The $m \times a L D$ probe hybridized most strongly to a $0.8 \mathrm{~kb}$ Pst $\mathrm{I}-\mathrm{Bam} \mathrm{HI}\left(\mathrm{P}_{3}-\mathrm{B}_{2}\right)$ fragment and more weakly to the adjacent $3.3 \mathrm{~kb}$ BamHI-Pst I $\left(\mathrm{B}_{1}-\mathrm{P}_{3}\right)$ fragment (Figs 1 and $\left.4 \mathrm{a}\right)$. The cloned $5.9 \mathrm{~kb}$ EcoRI and $8.5 \mathrm{~kb}$ HindIII fragments were probed with the Methylobacterium extorquens AM1 $m \times a A$ and $m \times a K$ probes, respectively, and in both cases, the strongest region of hybridization was to the $3.3 \mathrm{~kb} B a m \mathrm{HI}-P s t \mathrm{I}\left(\mathrm{B}_{1}-\mathrm{P}_{3}\right)$ and the $4.0 \mathrm{~kb}$ Pst $\mathrm{I}-P_{s t} \mathrm{I}\left(\mathrm{P}_{2}-\mathrm{P}_{3}\right)$ fragments located to the left of the $m \times a L D$-hybridizing region (Figs 1 and $4 \mathrm{~b}, \mathrm{c}$ ). The $m \times a A$ probe also hybridized weakly to the adjacent $1.2 \mathrm{~kb}$ SalI-Bam HI region $\left(\mathrm{S}_{1}-\mathrm{B}_{1}\right)$, and the $m \times a K$ probe hybridized more strongly to the $3.4 \mathrm{~kb} \mathrm{NruI}-\mathrm{NruI}\left(\mathrm{N}_{1}-\mathrm{N}_{2}\right)$ fragment than the adjacent $4 \mathrm{~kb}$ HindIII-NruI $\left(\mathrm{H}_{1}-\mathrm{N}_{1}\right)$ fragment. These data suggested that the region similar to $m \times a L D$ is located to the right of the region similar to $m \times a A$ and $m \times a K$, and the region similar to $m \times a K$ is

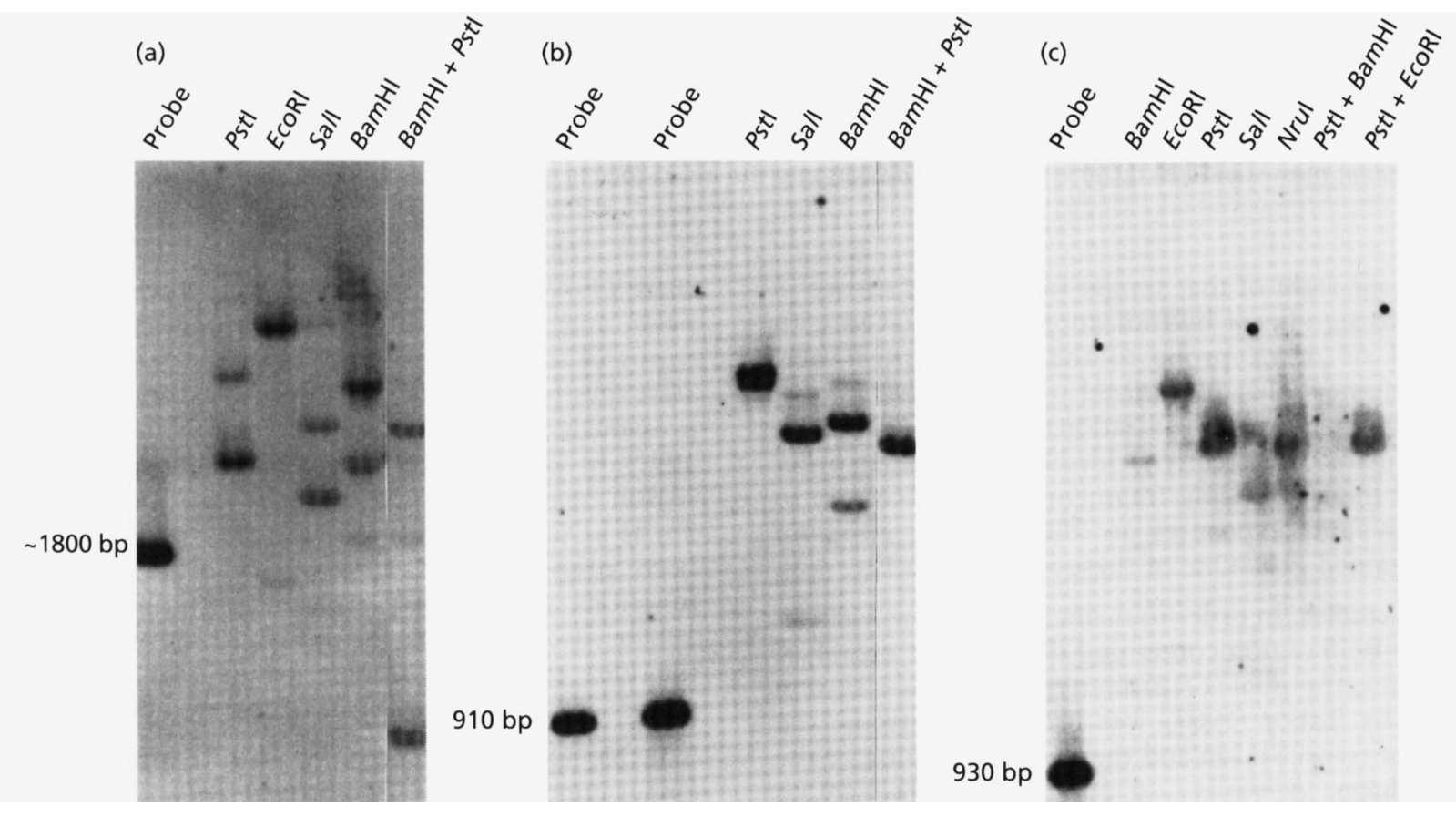

Fig. 4. Hybridization of the Methylobacterium extorquens AM1 mxa gene probes to restriction digests of the $8.5 \mathrm{~kb}$ HindIII or the $5.9 \mathrm{~kb}$ ECoRI Methylobacter albus BG8 fragments that hybridize to the mxaLD probe. Lanes denoted 'probe' contained purified probe DNA in each case. Conditions of hybridization allowed approximately $30 \%$ base pair mismatch (a) or $37 \% \mathrm{bp}$ mismatch ( $\mathrm{b}$ and $\mathrm{c}$ ). (a) mxaLD probe, digestions of the $8.5 \mathrm{~kb}$ Hindlll fragment; (b) mxaA probe, digestions of the $5.9 \mathrm{~kb}$ EcoRl fragment; (c) mxaK probe, digestions of the $8.5 \mathrm{~kb}$ Hindlil fragment. In each case, the larger Pstl fragment identified is $P_{2}-P_{3}(4.0 \mathrm{~kb})$ and the larger Sall fragment identified is $S_{2}-S_{3}(3.35 \mathrm{~kb})$. 
(a)

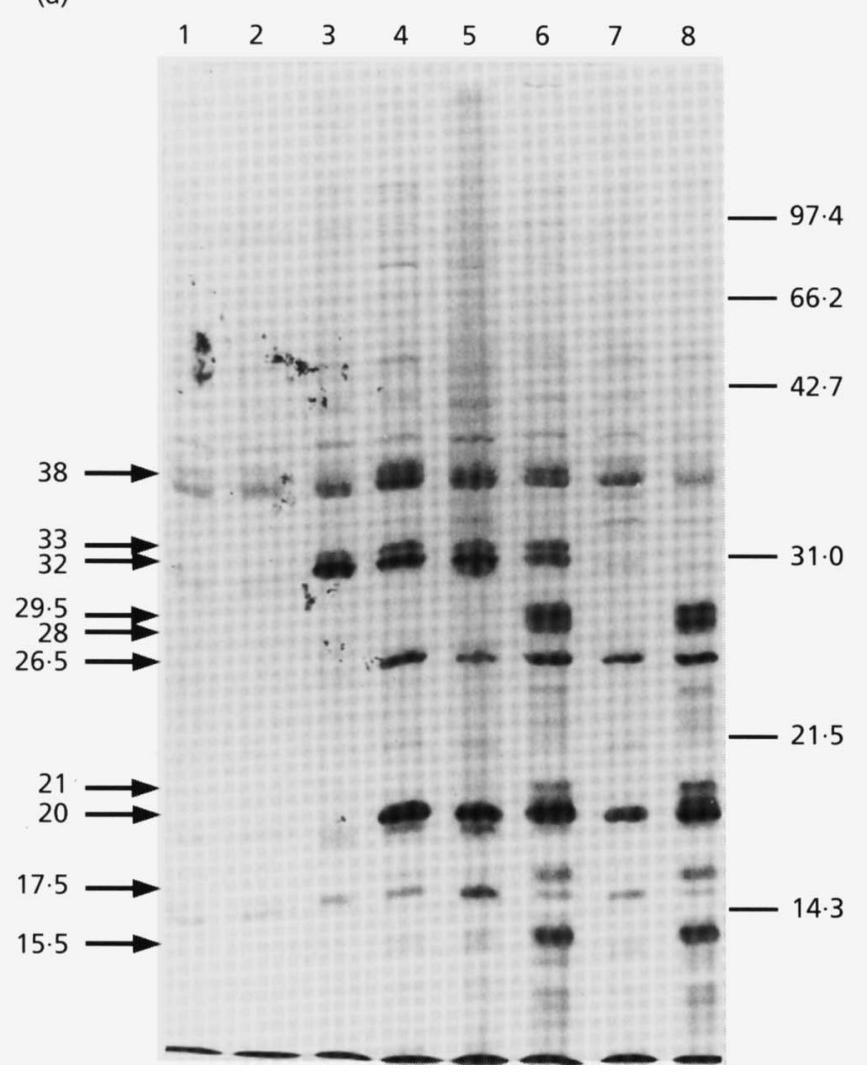

(b)

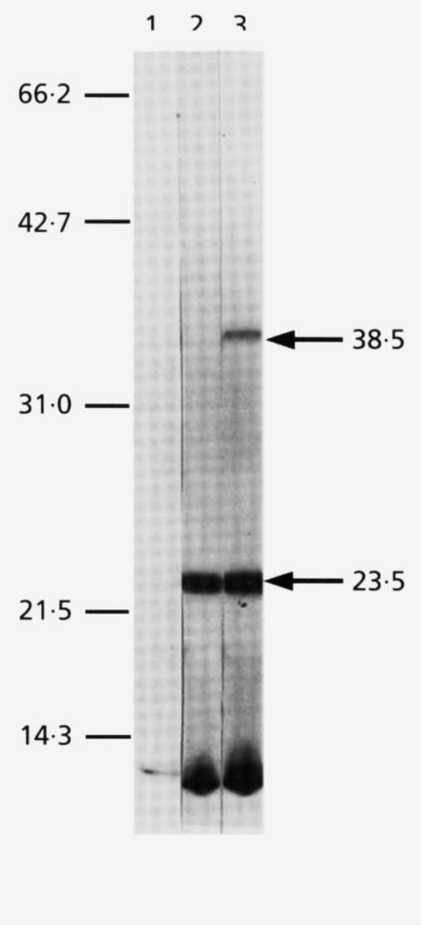

Fig. 5. Autoradiogram of polypeptides from whole-cell extracts labelled with [ ${ }^{35}$ S]methionine using the $T 7$ polymerase/promoter expression system and electrophoresed using $12 \%$ SDS-PAGE. $E$. coli DH5 $\alpha$ was the host for all constructs, and cells were induced for $20 \mathrm{~min}$. All fragment designations refer to Fig. 6 . (a) The first two lanes are vector controls with pT7-5 and pT7-6, respectively. The other lanes represent constructs of pT7-5 or pT7-6 containing the designated fragments, oriented left to right as shown in Fig. 6 with respect to the T7 promoter. Lanes: 3, pBMX834; 4,

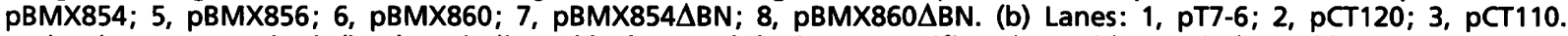
Molecular mass standards $(\mathrm{kDa})$ are indicated by bars and the insert-specific polypeptides are indicated by arrows.

located to the right of that similar to $m \times a A$, as shown in Fig. 1b. No significant hybridization was observed with the $m \times a A$ or $m \times a K$ probe to the $0.8 \mathrm{~kb}$ PstI-BamHI $\left(\mathrm{P}_{3}-\mathrm{B}_{2}\right)$ fragment that hybridized to the $m \times a L D$ probe. As shown in Fig. 4(c), hybridization of the $m \times a K$ probe to these fragments consistently yielded fuzzy bands. In order to identify the hybridizing fragments it was necessary to compare several exposures to the original ethidium bromide stained gels. One of these is shown in Fig. 4(c).

Expression studies. In order to further analyse the Metbylobacter albus BG8 region containing the putative $m \times a A, K$ and $L$ genes, the dual $T 7$ promoter/polymerase system described by Tabor (1987) was used to determine the direction of transcription and the size and location of the gene products. A variety of subclones of the $4.0 \mathrm{~kb}$ Bam $\mathrm{HI}\left(\mathrm{B}_{1}-\mathrm{B}_{2}\right)$ fragment containing the region that hybridized to the $m x a A, K$ and $L D$ probes were tested for expression in E. coli, and a total of seven polypeptides were consistently observed (Figs $5 \mathrm{a}$ and 6 ), all transcribed left to right as shown in Fig. 6. All seven of the polypeptides $(38,33,32,29 \cdot 5,28,26 \cdot 5$, and $20 \mathrm{kDa})$ were expressed from the Bam $\mathrm{HI}\left(\mathrm{B}_{1}-\mathrm{B}_{2}\right)$ fragment. Two sets of these $(33 / 32$ and $29 \cdot 5 / 28 \mathrm{kDa})$ were always observed as pairs, and are probably either unprocessed and mature forms of secreted polypeptides or the result of multiple start sites for the same polypeptide, as has been observed previously in this expression system (Chistoserdov et al., 1991). In some cases, as for pBMX834, insufficient coding region is available to encode two polypeptides of $33 / 32 \mathrm{kDa}$, further supporting this conclusion. It has been proposed that at least some of the $m \times a A K L$ functions should be periplasmic (Nunn \& Lidstrom, 1986b; Richardson \& Anthony, 1992), which supports the idea that these double bands may represent unprocessed and mature forms of secreted polypeptides.

The $33 / 32 \mathrm{kDa}$ polypeptides were expressed from all clones containing the $1.4 \mathrm{~kb} \mathrm{BamHI}-N r u \mathrm{I}\left(\mathrm{B}_{1}-\mathrm{N}_{1}\right)$ fragment, which is the region that hybridized most strongly to the $m x a A$ probe. The $38 \mathrm{kDa}$ polypeptide was only expressed from the plasmids containing DNA across the $\mathrm{N}_{1} N r u \mathrm{I}$ site, suggesting that the coding region for this polypeptide lies across this site. This coding region must initiate within a few tenths of a $\mathrm{kb}$ upstream of this site, to allow room for encoding the $33 / 32 \mathrm{kDa}$ polypeptide 


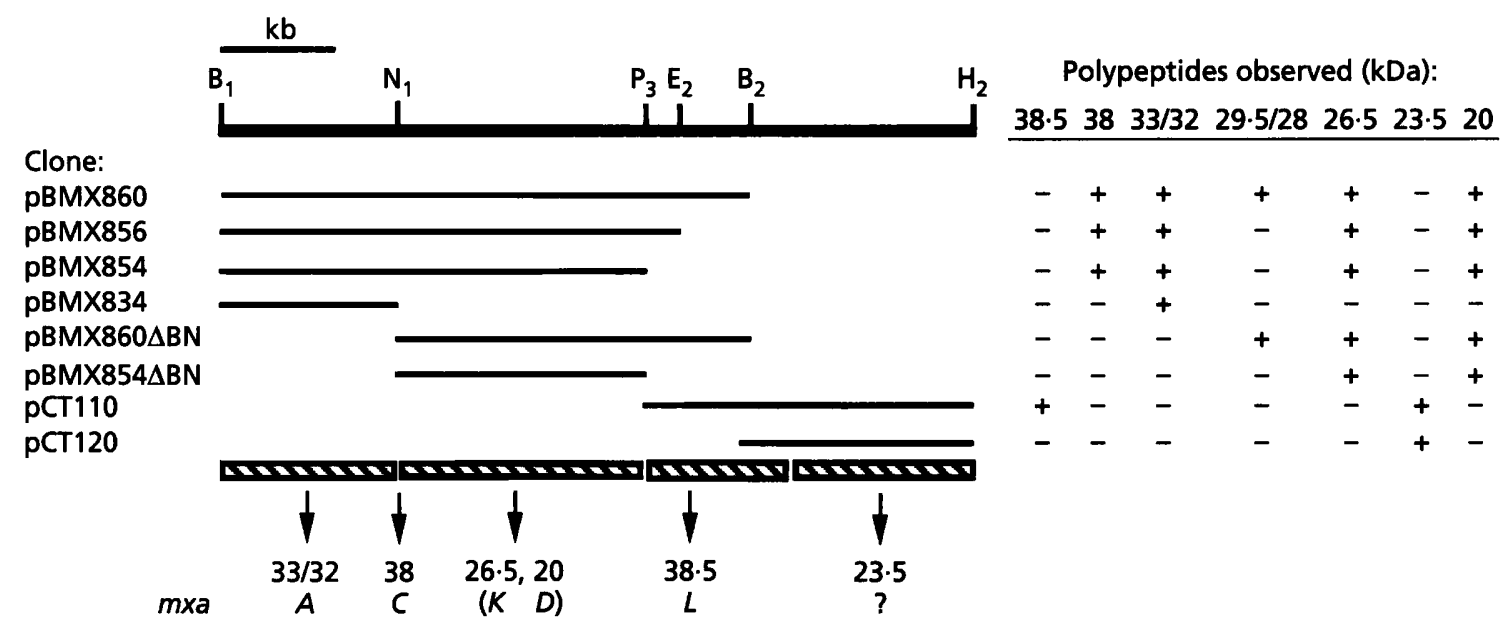

Fig. 6. Map of the clones used in the T7 expression experiments and the polypeptides observed from each. In all cases, the polypeptides were only observed when the indicated fragments were cloned into the appropriate expression vector such that the orientation with respect to the $\mathrm{T} 7$ promoter was left to right, as shown. Restriction sites are the same as in Fig. 1(b). The 29.5/28 kDa pair of polypeptides appear to be truncated forms of the $38.5 \mathrm{kDa}$ polypeptide (see text).

upstream. Preliminary sequencing of the region around the $\mathrm{N}_{1} \mathrm{NruI}$ site revealed a partial ORF with $39 \%$ identity to the Metbylobacterium extorquens AM1 $m \times a C$ across a 118 amino acid overlap (A. Springer \& M. Lidstrom, unpublished data), suggesting that the $38 \mathrm{kDa}$ polypeptide corresponded to $\mathrm{MxaC}$. The 26.5 and $20 \mathrm{kDa}$ polypeptides were expressed from all clones containing the $1.6 \mathrm{~kb}$ NruI-Pst $\mathrm{I}\left(\mathrm{N}_{1}-\mathrm{P}_{3}\right)$ fragment, just downstream of the region encoding the $33 / 32 \mathrm{kDa}$ polypeptides. This was the region that hybridized most strongly to the $m \times a K$ probe, but it also hybridized to the $m \times a L D$ probe. The region from the $B_{1}$ site to the $P_{3}$ site contains just enough coding potential for all of these polypeptides, assuming that the $33 / 32 \mathrm{kDa}$ polypeptides are encoded by the same gene. The $29 \cdot 5 / 28 \mathrm{kDa}$ polypeptides were expressed from both clones containing the complete NruI-BamHI $\left(\mathrm{N}_{1}-\mathrm{B}_{2}\right)$ fragment that includes DNA downstream of the region encoding the 26.5 and $20 \mathrm{kDa}$ polypeptides. This downstream region hybridized most strongly to the $m \times a L D$ probe. In addition, three other poorly expressed polypeptides of $21,17.5$ and $15.5 \mathrm{kDa}$ showed the same pattern of expression as the $29 \cdot 5 / 28 \mathrm{kDa}$ polypeptides. However, none of these were expressed from clones missing the right-hand $0.5 \mathrm{~kb} E c o \mathrm{RI}-\mathrm{BamHI}\left(\mathrm{E}_{2}-\mathrm{B}_{2}\right)$ or $0.8 \mathrm{~kb}$ Pst $\mathrm{I}-$ Bam $\mathrm{HI}\left(\mathrm{P}_{3}-\mathrm{B}_{2}\right)$ fragments. This indicates that none of these polypeptides are wholly encoded upstream of the EcoRI site denoted $\mathrm{E}_{2}$ on Fig. 6. These data strongly suggest that the smaller three polypeptides are artefacts, either breakdown products or the result of internal start sites, and that the $29 \cdot 5 / 28 \mathrm{kDa}$ pair are encoded by a gene that has a start located in the region of the $P s t \mathrm{I}$ site denoted $\mathrm{P}_{3}$ in Fig. 6. Preliminary sequencing upstream of the $E_{2}$ site revealed a partial ORF that showed $31 \%$ identity to mxaL of Metbylobacterium extorquens AM1 across 39 amino acids (A. Springer \& M. Lidstrom, unpublished data). In Metbylobacterium extorquens AM1, mxaL is predicted to encode a $37 \mathrm{kDa}$ polypeptide, suggesting that this gene might extend across the $B_{2}$ site. In order to test this hypothesis, two other subclones were used for expression that include DNA past that site to the HindIII site $\left(\mathrm{H}_{2}\right)$ (Figs $5 \mathrm{~b}$ and 6). In both cases, none of the polypeptides observed from the $\mathrm{B}_{1}-\mathrm{B}_{2}$ clones were present. For the $\mathrm{P}_{3}-\mathrm{H}_{2}$ subclone, two new polypeptides of 38.5 and $23.5 \mathrm{kDa}$ were present, while in the smaller $\mathrm{B}_{2}-\mathrm{H}_{2}$ subclone, only the $23.5 \mathrm{kDa}$ polypeptide was present (Fig. 5b). These data suggest that the $29 \cdot 5 / 28 \mathrm{kDa}$ polypeptides represent truncated products of a gene equivalent to $m \times a L$, that crosses the $\mathrm{B}_{2}$ site and encodes a $38.5 \mathrm{kDa}$ polypeptide. The $23.5 \mathrm{kDa}$ polypeptide must be encoded downstream of the $38.5 \mathrm{kDa}$ polypeptide.

\section{Complementation of Methylobacterium extorquens AM1 MxaA, $K$ and $L$ mutants}

The results presented above suggest that Methylobacter albus BG8 contains genes equivalent to the $m \times a A, K$ and $L$ genes of Metbylobacterium extorquens AM1. Having cloned and localized these $m \times a$ genes and also shown their expression in $E$. coli, we attempted to complement the $\mathrm{MxaA}, \mathrm{K}$ and $\mathrm{L}$ mutants of Metbylobacterium extorquens AM1 using various constructs of Metbylobacter albus DNA in the broad-host-range vector $\mathrm{pRK} 310$. These included the larger HindIII, EcoRI and Bam HI fragments $\left(\mathrm{H}_{1}-\mathrm{H}_{2}\right.$, $\left.\mathrm{E}_{1}-\mathrm{E}_{2}, \mathrm{~B}_{1}-\mathrm{B}_{2}\right)$, cloned in both orientations, the PstI-HindIII $\left(\mathrm{P}_{3}-\mathrm{H}_{2}\right)$ fragment cloned right to left with respect to the lac promoter in $\mathrm{pRK} 310$ and the PstI-EcoRI $\left(\mathrm{P}_{3}-\mathrm{E}_{2}\right)$ fragments cloned left to right with respect to the lac promoter in pRK310 (Fig. 1). These clones were mated into the appropriate Metbylobacterium extorquens AM1 $\mathrm{MxaA}, \mathrm{K}$ and $\mathrm{L}$ mutants and after a 2 -week incubation, colonies containing the test clones were compared to controls. Positive controls were wild-type and mutants complemented with the appropriate Metbylobacterium extorquens AM1 clones, and negative controls were the mutants containing vector alone. No growth was observed for 
(a)

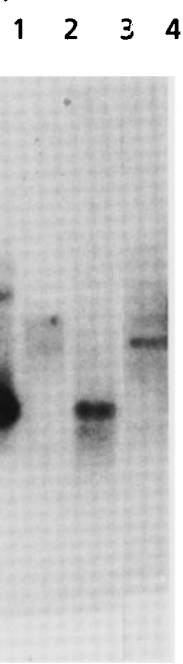

(b)

$\begin{array}{llll}1 & 2 & 3 & 4\end{array}$

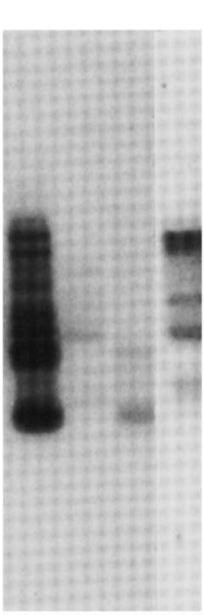

(c)

$\begin{array}{llll}1 & 2 & 3 & 4\end{array}$

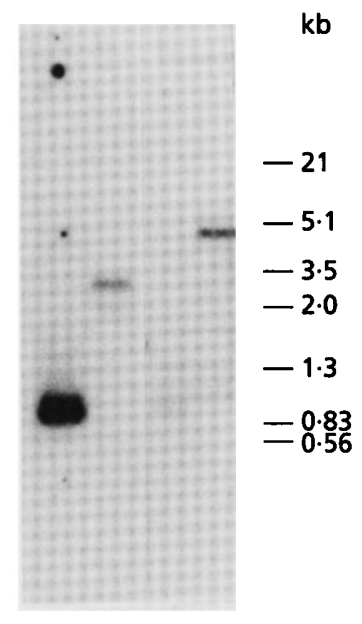

Fig. 7. Hybridization of the isolated Methylobacter albus BG8 $m \times a A, C K$ and $L$ probes to DNA from methanotrophs. Probes: (a) $m \times a A$; (b) $m \times a C K$; (c) $m \times a L$. Lanes: 1, Methylobacter albus BG8; 2, Methylococcus capsulatus Bath; 3, Methylocystis parvus OBBP; 4, Methylobacter marinus A45. Sizes of standards are shown on the right. Chromosomal DNA was digested with BstYI.

cells containing the test clones above that seen with the negative controls. In all cases, the same mating mixtures plated onto medium containing succinate plus tetracycline produced a large number of colonies as compared to negative controls with no vector, confirming that plasmid transfer had occurred.

\section{Hybridization to methanotroph DNA}

Three subclones of the Metbylobacter albus BG8 BamHI fragment containing the putative $\operatorname{mxa} A, C K$ and $L$ regions were used as hybridization probes to genomic digests of DNA from three of the methanotrophs that showed hybridization to the Metbylobacterium extorquens AM1 $m \times a L$ probe. The three subclones were $B_{1}-N_{1}$, which should contain mainly $m \times a A, \mathrm{~N}_{1}-\mathrm{P}_{3}$, which should contain $m \times a K$ and the major portion of $m \times a C$, and $\mathrm{P}_{3}-\mathrm{B}_{2}$, which should be specific to $m \times a L$ (Fig. 1). The strains tested were Metbylococcus capsulatus Bath, a Type X strain, Metbylocystis parvus OBBP, a Type II strain and Metbylobacter marinus A45, a Type I strain. Metbylobacter albus BG8 DNA was used as a control. Hybridization to the DNA from the other methanotrophs was observed in all cases with all three probes, although it was not as strong as that with Metbylobacter albus BG8 (Fig. 7). In the case of Metbylococcus capsulatus Bath, the major bands that hybridized to each of the three probes were of different sizes. However, for the other two strains, the $m \times a C K$ probe hybridized to two bands that were the same size as the bands detected by the $m \times a A$ and $m \times a L$ probes, respectively. In the case of Metbylobacter marinus A45, other bands were also detected by the $m \times a C K$ probe. These data suggest that in Metbylocystis parvus OBBP and Metbylobacter marinus $\mathrm{A} 45$, the $m \times a C K$ region lies between the $m \times a A$

and $m \times a L$ regions, just as it does in Metbylobacter albus BG8 and Metbylobacterium extorquens AM1.

\section{DISCUSSION}

The methanol oxidation (Mox) system in the facultative methanol utilizers appears to be complex, requiring a large number of genes to carry out the single biochemical step of converting methanol to formaldehyde (Anderson \& Lidstrom, 1988; Lidstrom, 1990; Machlin et al., 1988; Nunn \& Lidstrom, 1986a; Lidstrom et al., 1994). These functions include the structural genes for the MDH and its electron acceptor $\left(\operatorname{cyt} c_{\mathrm{L}}\right)$, genes involved in synthesis of the cofactor PQQ, regulatory genes, and genes necessary for assembly (Anderson \& Lidstrom, 1988; Lidstrom, 1990; Nunn \& Lidstrom, 1986a). Previous work has shown that the MxaF polypeptides from a variety of methylotrophs show similarity (Anthony, 1986), and that the genes encoding the large subunit of the $\mathrm{MDH}$ are also conserved (Anderson et al., 1990; Harms et al., 1987; Machlin \& Hanson, 1988; Stephens et al., 1988).

The results presented here suggest that some of the other genes in the Mox system are also conserved among methane and methanol utilizers, based on specific hybridization of genomic fragments to $m x a A, K$ and $L D$ probes. These $m \times a$ genes are involved in producing a functional $\mathrm{MDH}$ holoenzyme, consisting of the $\mathrm{MDH}$ apoprotein, its cofactor PQQ, and calcium (Richardson \& Anthony, 1992), and therefore might be expected to be present in other Mox systems. The hybridization between Metbylobacterium extorquens AM1 $m \times a$ genes and methanotrophic DNA was strongest for the $m \times a L D$ probe and much weaker for the $m \times a A$ and $m \times a K$ probes. In the case of Metbylobacter albus BG8, an $8.5 \mathrm{~kb}$ HindIII fragment was isolated that hybridized to all three Metbylobacterium extorquens AM1 probes, and each probe hybridized to a specific set of subfragments. In this case, the hybridization was strongest to the $m \times a L D$ probe and weaker to the $m \times a K$ probe, as with the genomic digests, but it was surprisingly strong to the $m x a A$ probe. It is not clear why the $m \times a A$ probe hybridized better to the cloned fragment than the genomic digests, while the $m \times a K$ probe hybridized weakly in both cases. In side-by-side hybridizations under the same conditions, the same results were always obtained. Fragments containing the $m \times a A, C K$ and $L$ regions of Metbylobacter albus BG8 detected specific bands of genomic DNA from other methanotrophs, and in the case of the Type II strain Metbylocystis parvus OBBP and the Type I strain Metbylobacter marinus A45, the hybridization pattern suggested that the order of the genes was the same as in Metbylobacter albus BG8 and Metbylobacterium extorquens AM1.

Expression studies of the cloned Metbylobacter albus BG8 fragment showed that the region of hybridization to the Metbylobacterium extorquens AM1 mxa $A K L$ genes encoded five polypeptides, and a sixth was encoded downstream of these in a region that did not show significant hybridization to the $m \times a A K L$ probes. Recent data have shown that the $m \times a A K L$ region of Metbylobacterium extorquens AM1 contains five genes, $m \times a A C K L D$, with calculated 
molecular masses of $33 \cdot 7 / 31 \cdot 8,37 \cdot 5,23,35 \cdot 6 / 32 \cdot 6$ and $18.5 / 16.6 \mathrm{kDa}$, respectively, with the pairs representing the mature and processed forms of putative periplasmic and membrane polypeptides (Morris et al., 1995). However, attempts to express these genes in an $E$. coli expression system were not successful, with the exception of $m \times a D$. In our study, these five genes were all expressed in $E$. coli. The region that hybridized to the $m \times a A$ probe expressed a polypeptide of $33 / 32 \mathrm{kDa}$, the region that hybridized to the $m \times a K$ probe and also hybridized weakly to the $m \times a L D$ probe expressed polypeptides of 26.5 and $20 \mathrm{kDa}$, and the region that hybridized well to the $m \times a \mathrm{LD}$ probe expressed a polypeptide of $38.5 \mathrm{kDa}$. In addition, preliminary sequencing across the $\mathrm{N}_{1} \mathrm{NruI}$ site revealed the presence of a gene with identity to $m \times a C$ and preliminary sequencing across the $\mathrm{E}_{2}$ EcoRI site revealed the presence of a gene with identity to $m \times a L$. These data suggest that the $33 / 32 \mathrm{kDa}$ polypeptide corresponds to $m \times a A$, the $38 \mathrm{kDa}$ polypeptide corresponds to $m \times a C$, the $26.5 \mathrm{kDa}$ polypeptide corresponds to $m \times a K$, the $20 \mathrm{kDa}$ polypeptide corresponds to $m \times a D$ and the $38.5 \mathrm{kDa}$ polypeptide corresponds to mxaL. Fig. 6 shows the assumed sizes of these genes, based on the expression data. The region involved in both hybridization and expression is just large enough to encode all of these polypeptides. The identity of the $23.5 \mathrm{kDa}$ polypeptide expressed in the region downstream of $m \times a L$ is not known. These data suggest that the relative order of $m \times a L$ and $D$ is reversed in Methylobacter albus BG8 compared to Metbylobacterium extorquens AM1. It is not yet known whether $m \times a D$ has a function in calcium acquisition by MDH. Our data do not allow us to determine the order of $m \times a K$ and $D$.

Despite the evidence outlined above that $m \times a A, K$ and $L$ are present in Metbylobacter albus BG8, we were unable to demonstrate functional complementation of Metbylobacterium extorquens AM1 MxaA, $\mathrm{K}$ and $\mathrm{L}$ mutants. The lack of heterologous complementation could be due to lack of expression, insufficient functional similarity, or both. The T7 expression data suggest that one of the fragments tested $\left(\mathrm{H}_{1}-\mathrm{H}_{2}\right)$, contains complete $m \times a A, K$ and $L$ and two of them $\left(\mathrm{E}_{1}-\mathrm{E}_{2}\right.$ and $\left.\mathrm{B}_{1}-\mathrm{B}_{2}\right)$ contain complete $m \times a A$ and $m \times a K$ genes. Therefore, these clones should have complemented the Metbylobacterium extorquens AM1 mutants. However, earlier studies indicated that a Metbylobacterium extorquens AM1 MxaF mutant could only be complemented by the Methylobacter albus BG8 mxaF when small subclones (less than $5 \mathrm{~kb}$ ) were used (Stephens et al., 1988). Larger subclones containing $m \times a F$ did not complement, presumably reflecting difficulties in expression. $\mathrm{MxaA}$ and $\mathrm{K}$ mutants of Metbylobacterium organophilum XX and Metbylobacterium extorquens AM1 have been complemented with DNA from a Type II methanotroph, Metbylosinus methanica (Bastien et al., 1989). Therefore, at least in some instances functional conservation is sufficient for complementation. Further work will be necessary to determine whether expression occurs in Metbylobacterium extorquens AM1 but the gene products are not functional, or whether expression does not occur.

In Methylobacterium extorquens AM1, $m \times a F$ (encoding the
$60 \mathrm{kDa}$ subunit of the MDH) is located in a gene cluster adjacent to the $m \times a A, K$ and $L$ genes in the order F-J-G-I-R-S-A-C-K-L-D (Lidstrom, 1990; Morris et $a l ., 1995)$. The distance between $m \times a F$ and $m \times a A$ in Metbylobacterium extorquens AM1 is approximately $5 \mathrm{~kb}$ (Lidstrom, 1990). However, an analysis of the restriction fragments for the Metbylobacter albus BG8 $m \times a F$ and $m x a A, K$ and $L$ clones shows no overlap on either side, and so these genes must be separated by at least $6 \mathrm{~kb}$ (Stephens et al., 1988).

Genetic studies of the Mox system in obligate methanotrophs are difficult, as mutants in this system are lethal and conditional mutants are difficult to obtain. Therefore, we have approached these studies with surrogate genetics, using metabolically related organisms as model systems. The cloning of two sets of Mox genes from Metbylobacter albus BG8 ( $m \times a F$ and the $m \times a A, C, K, D$ and $L$ genes) now opens the way to studies of coordinated gene expression in this important group of bacteria.

\section{ACKNOWLEDGEMENTS}

This work was supported by a grant from the Department of Energy (\#DEFGO-87ER13753) to M.E.L. and a postdoctoral travel grant from the Korea Science and Engineering Foundation to Y.M.K.

\section{REFERENCES}

Anderson, D. J. \& Lidstrom, M. E. (1988). The moxFG region encodes four polypeptides in the methanol-oxidizing bacterium Metbylobacterium sp. strain AM1. J Bacteriol 170, 2254-2262.

Anderson, D. J., Morris, C. J., Nunn, D. N., Anthony, C. \& Lidstrom, M. E. (1990). Nucleotide sequence of the Metbylobacterium extorquens sp. AM1 moxF and $G$ genes involved in methanol oxidation. Gene 90, 173-176.

Anthony, C. (1986). Bacterial oxidation of methane and methanol. Adv Microbiol Physiol 27, 113-209.

Anthony, C., Ghosh, M. \& Blake, C. C. F. (1994). The structure and function of methanol dehydrogenase and related quinoproteins containing pyrroloquinoline quinone. Biochem J 304, 665-674.

Bastien, C., Machlin, S., Zhang, Y., Donaldson, K. \& Hanson, R. (1989). The organization of genes required for the oxidation of methanol to formaldehyde in three Type II methylotrophs. Appl Environ Microbiol 55, 3124-3130.

Bowman, J., Sly, L. I., Nichols, P. D. \& Hayward, A. C. (1993). Revised taxonomy of the methanotrophs: description of Methylobacter gen. nov., emendation of Metbylococcus, validation of Metbylosinus and Metbylocystis species, and a proposal that the family Metbylococcaceae include only the group I methanotrophs. Int J Syst Bacteriol 43, 735-753.

Boyer, H. W. \& Roulland-Dussoix, D. (1969). A complementation analysis of the restriction and modification of DNA in Eschericbia coli. J Mol Biol 41, 459-472.

Chistoserdov, A. Y., Tsygankov, Y. D. \& Lidstrom, M. E. (1991). Genetic organization of methylamine utilization genes from Metbylobacterium extorquens AM1. J Bacteriol 173, 5901-5908.

Ditta, G. T., Schmidhauser, T., Yakobson, E., Lu, P., Liang, X., Finlay, D., Guiney, D. \& Helinski, D. (1985). Plasmids related to the broad host range vector, pRK290, useful for gene cloning and monitoring gene expression. Plasmid 13, 149-153. 
Figurski, D. \& Helinski, D. R. (1979). Replication of an origincontaining derivative of the plasmid RK2 dependent on a plasmid function provided in trans. Proc Natl Acad Sci US A 76, 1648-1652.

Harder, W., Attwood, M. M. \& Quayle, J. R. (1973). Methanol assimilation by Hyphomicrobium sp. $J$ Gen Microbiol 78, 155-163.

Harms, N., de Vries, G. E., Maurer, K., Hoogendijk, J. \& Stouthamer, A. H. (1987). Isolation and nucleotide sequence of the methanol dehydrogenase structural gene from Paracoccus denitrificans. J Bacteriol 169, 3969-3975.

Holmes, D. S. \& Quigley, M. (1981). A rapid boiling method for the preparation of bacterial plasmids. Anal Biochem 114, 193-197.

Hou, C. T. (1984). Metbylotrophs: Microbiology, Biochemistry and Genetics. Boca Raton, FL: CRC Press.

Ish-Horowicz, D. \& Burke, J. F. (1981). Rapid and efficient cosmid vector cloning. Nucleic Acids Res 9, 2989-2998.

Knauf, V. C. \& Nester, E.W. (1982). Wide host range cloning vectors : cosmid clone bank of Agrobacterium Ti plasmids. Plasmid 8, 45-54.

Lidstrom, M. E. (1988). Isolation and characterization of marine methanotrophs. Antonie Leeuwenboek 54, 189-199.

Lidstrom, M. E. (1990). Genetics of carbon metabolism in methylotrophic bacteria. FEMS Microbiol Rev 87, 431-436.

Lidstrom, M. E., Anthony, C., Biville, C., Gasser, F., Goodwin, P., Hanson, R. S. \& Harms, N. (1994). New unified nomenclature for genes involved in the oxidation of methanol in Gram-negative bacteria. FEMS Microbiol Lett 117, 103-106.

Machlin, S. M. \& Hanson, R. S. (1988). Nucleotide sequence and transcriptional start site of the Methylobacterium organophilum XX methanol dehydrogenase structural gene. J Bacteriol 170, 4739-4747.

Machlin, S. M., Tam, P. E., Bastien, C. A. \& Hanson, R. S. (1988). Genetic and physical analysis of Methylobacterium organophilum XX genes encoding methanol oxidation. J Bacteriol 170, 141-148.

Maniatis, T., Fritsch, E. F. \& Sambrook, J. (1982). Molecular Cloning: a Laboratory Manual. Cold Spring Harbor, NY : Cold Spring Harbor Laboratory.

Marmur, J. (1961). A procedure for the isolation of deoxyribonucleic acid from micro-organisms. J Mol Biol 3, 208-218.

Meinkoth, J. \& Wahl, G. (1984). Hybridization of nucleic acids immobilized on solid supports. Anal Biochem 138, 267-284.

Morris, C. J., Springer, A. L., Kim, Y. M., Perkins, K. E. \& Lidstrom, M. E. (1995). The identification and nucleotide sequence of $m \times a A$, $m \times a C, m \times a K, m \times a L$ and $m \times a D$ genes from Metbylobacterium extorquens AM1. $J$ Bacteriol (in press).

Nunn, D. N. \& Lidstrom, M. E. (1986a). Isolation and complementation analysis of 10 methanol oxidation mutant classes and identification of the methanol dehydrogenase structural gene of Metbylobacterium sp. strain AM1. J Bacteriol 166, 581-590.

Nunn, D. N. \& Lidstrom, M. E. (1986b). Phenotypic characterization of 10 methanol oxidation mutant classes in Metbylobacterium sp. strain AM1. J Bacteriol 166, 591-597.

Richardson, I. W. \& Anthony, C. (1992). Characterization of mutant forms of the quinoprotein methanol dehydrogenase. Biochem J 287, 709-715.

Rigby, P. W. J., Dieckmann, M., Rhodes, C. \& Berg, P. (1977). Labeling deoxynucleic acid to high specific activity in vitro by nick translation with DNA polymerase I. J Mol Biol 113, 237-251.

Staley, J. T. (1981). The genera Prosthecomicrobium and Ancalomicrobium. In The Prokaryotes, pp. 456-460. Edited by M. P. Starr, H. Stolp, H. G. Trüper, A. Balows \& H. G. Schlegel. New York: Springer-Verlag.

Stephens, R. L., Haygood, M. G. \& Lidstrom, M. E. (1988). Identification of putative methanol dehydrogenase $(\operatorname{mox} F)$ structural genes in methylotrophs and cloning of $\operatorname{mox} F$ genes from Metbylococcus capsulatus Bath and Methylomonas albus BG8.J Bacteriol 170, 2063-2069.

Tabor, S. (1987). Expression using the T7 RNA polymerases/ promoter system, section 16.2.1-11. In Current Protocols in Molecular Biology. Edited by F. A. Ausubel. New York: Greene Publishing \& Wiley Interscience.

Thompson, A. M. \& Cicerone, R. J. (1986). Atmospheric $\mathrm{CH}_{4}, \mathrm{CO}$ and $\mathrm{OH}$ from 1860 to 1985 . Nature 321, 148-150.

White, S., Boyd, G., Mathews, F. S., Xia-Zxa Dai, W. W., Xhang, Y. F. \& Davidson, V. L. D. (1993). The active-site structure of the calcium-containing quinoprotein methanol dehydrogenase. $J$ Biochem 32, 12955-12958.

Whittenbury, R. \& Dalton, H. (1981). The methylotrophic bacteria. In The Prokaryotes, pp. 894-902. Edited by M. P. Starr, H. Stolp, H. G. Trüper, A. Balows \& H. G. Schlegel. New York: SpringerVerlag.

Whittenbury, R., Phillips, K. C. \& Wilkinson, J. F. (1970). Enrichment, isolation and some properties of methane-utilizing bacteria. J Gen Microbiol 61, 205-218.

Received 21 April 1995; revised 25 July 1995; accepted 31 July 1995. 